\title{
An Analysis of the Hot Topics and Trends in Research on Innovation and Entrepreneurship Education at Chinese Universities
}

\author{
Lingna Zhang*, Fang Liu
}

\author{
Beijing Union University, Beijing, China \\ *Corresponding author. Email: lingna.zhang@buu.edu.cn
}

\begin{abstract}
During the past few years, in keeping with the requirement of development in various aspects of the Chinese economy and society, the innovation and entrepreneurship education in the Chinese universities has become a hot topic of research with respect to scholars at home and abroad. Taking the periodicals included by CNKI in the category of CSSCI as its research scope, this article has gathered the research literature entitled "innovation and entrepreneurship education at universities" during the years 2008 through 2019. With the help of a scientific visualization software called CiteSpace, the article has made a statistic analysis of the issues such as evolution of the innovation and entrepreneurship education, its knowledge exchange and current situation of cooperation from the perspective of bibliometrics before revealing the characteristics of research on Chinese innovation and entrepreneurship education and its law of development and pointing out the research trend concerning the innovation and entrepreneurship education in the universities.
\end{abstract}

Keywords: Innovation and entrepreneurship education at universities, Hot research topics, Research trend.

\section{INTRODUCTION}

Currently, innovation and entrepreneurship education has risen as China's national strategies. The initiation of innovation and entrepreneurship education in various universities is of great practical significance to the healthy development of higher education, economic progress and social employment. ${ }^{[1]}$ Despite the year-by-year increase in the number of the articles on the issue of the innovation and entrepreneurship at universities with respect to the academic circle and the increasing enhancement in terms of the width and depth of such research, there are not many articles intended for tacking and analyzing the hot topic on innovation and entrepreneurship education. Based upon the strength of CiteSpace as a map of scientific knowledge, this article has made a visualization analysis of the research achievements of the Chinese academic circle on the issue of the innovation and entrepreneurship at universities so as to provide reference for the further research and exploration of such education in the universities.

The research on innovation and entrepreneurship education has, in recent years, become popular. Scholars have made fruitful achievements of research from different perspectives, which are mainly embodied in the following aspects. First, they have made a comprehensive interpretation and analysis of the concept and connotation of innovation and entrepreneurship education. Second, they have succeeded in exploring the construction of the practice patterns of different types and in different forms regarding the innovation and entrepreneurship education at universities from their own environments. Third, as to how to construct a talent cultivation system for the innovation and entrepreneurship education in the universities, they believe that the cultivation of innovative and entrepreneurial talents with respect to universities is a demand not only from the reform of higher education but also from social and economic development. Therefore, a university should establish a clear development orientation and emphasize the construction of an integrated talent cultivation system. Fourth, they have discussed such issues as the need for, and the path of, integration between innovation and entrepreneurship education and specialized education on the one hand and ideological and political education on the other, thinking that the introduction of innovation and entrepreneurship education to specialized education and ideological and political education is an indispensable approach to the cultivation of innovative talents. Additionally, they have 
given concrete paths and suggestions in that regard. In other words, the number of the research articles on the issue of innovation and entrepreneurship education at universities is characterized by the increase with each passing year as well as incessant enhancement in terms of scope and depth. In order to explore the characteristics and law of research on the innovation and entrepreneurship education in our country and shed light on the trend of research on innovation and entrepreneurship education at universities, this research, based on the data base of CNKI and taking the articles on innovation and entrepreneurship education at universities from 2008 to 2019 as its research object, has made a statistical analysis in several aspects such as research topic, number, source periodicals and the cooperation between authors and scientific research institutions before uncovering the features and law of research on the innovation and entrepreneurship education in China.

\section{DATA SOURCES AND RESEARCH METHOD}

The data used in this article come from the CSSCI data base of CNKI and the research and analysis are conducted by adopting CiteSpace, a visualization information software product developed by Chen Meichao, who is a professor from Drexel University and specialize in computer and information science.

\subsection{Data Sources}

The data of the articles gathered in this research mainly come from the CSSCI advanced search in CNKI. Through different search terms, an analysis of the obtained search results has been made. Finally, "innovation and entrepreneurship education" is finalized as the search term with the field limited to "topic" and unlimited search time. Based upon the aforementioned search condition, a total of 825 related articles were searched. After a further sifting, with the exception of non-biographical materials, reports, commentaries and related but invalid published articles, 810 articles were ultimately used as the object of analysis.

\subsection{Research Method}

In this article, a visualization software called CiteSpace developed by Prof. Chaomei Chen who comes from Drexel University and specializes in computer and information science is used to conduct research and analysis. CiteSpace is the abbreviation of Citation Space. Dedicated to the analysis of the potential knowledge in scientific literature, CiteSpace is a multivariate, time-sharing and dynamic visualization citation analysis software which has been gradually developed in the context of scientific metrology and visualization of data and information. Due to the structure, law and distribution of scientific knowledge presented through visualization method, the visualization graphics analyzed and obtained through this method are also called "map of scientific knowledge"[3].

\section{RESEARCH FINDINGS}

\subsection{Bibliometric Analysis}

An important index for measuring the development of a field is the change in terms of the number of academic articles. Making a historical and comprehensive statistical analysis of the literature distribution and drawing the corresponding distribution curve are of great significance to the evaluation of the stage of the field and prediction of its developmental trend and dynamic state ${ }^{[4]}$. The research on innovation and entrepreneurship education at universities with respect to the academic circle in China began to emerge in 2008. Judging from Figure 1, the number of published articles follows the tendency of increase on the whole. Generally speaking, with 2014 as a boundary, the research on innovation and entrepreneurship education at universities with respect to the academic circle in China can be divided into two stages. The first stage is the period ranging from 2008 to 2014 when the number of the published article in that regard is about 20, which can be said to be the initial stage as far as innovation and entrepreneurship education at universities is concerned. The second stage is the period ranging from 2014 to this day when the number of the published article in that regard is characterized by an exponential growth with the year of 2015 being the most remarkable and the percentage of increase reaching as high as $251.72 \%$. During this stage, articles of this kind are characterized by an increase in number and abundance in content. It is predicted that in the upcoming years, the amount of the articles on innovation and entrepreneurship education at universities will take on a tendency of growth.

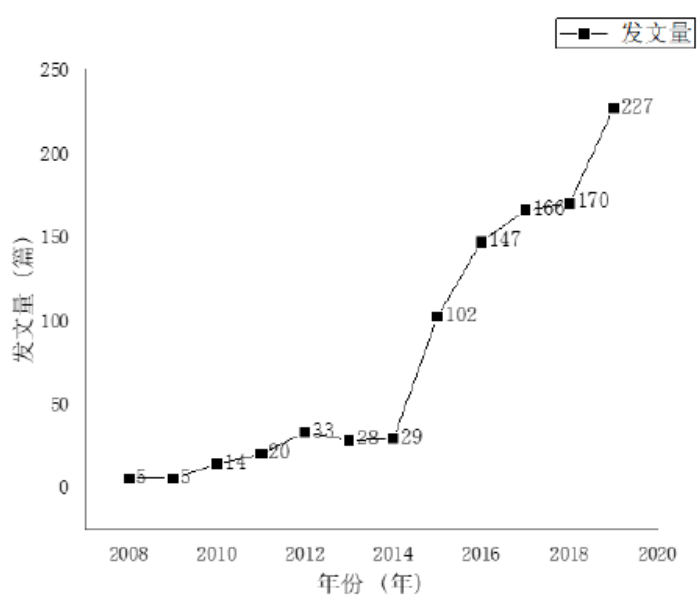

Figure 1 Annual distribution of the articles about the research on innovation and entrepreneurship education at universities 


\subsection{Distribution of Source Periodicals}

In this article, the periodicals with the number of published articles about the research on innovation and entrepreneurship education at universities reaching five or more are selected for analysis (see Table 1). It can be found that China Higher Education Research by the China Association of Higher Education, China Higher Education by the China Education Press Agency and Modern Education Management by the Liaoning Academy of Education have the largest number of published articles about the education. Each of the three periodicals has 10 articles of this kind. In the second place are the periodicals such as Research in Higher Education of Engineering, Heilongjiang Researches on Higher Education, Jiangsu Higher Education and China University Teaching, with each of them having 9 articles in that regard. In the third place are periodicals including Ideological Theoretical Education and Research in Education Development. It can be seen that the source periodicals about the education of innovation and entrepreneurship come from Beijing and Central China. And the data above indicate that the objects of the innovation and entrepreneurship education at universities are mainly distributed in North China.

Table 1. Table of the periodicals with the number of published articles about the education of innovation and entrepreneurship at universities in China reaching five or more

\begin{tabular}{lll}
\hline Serial number & names of periodicals & Number of published articles \\
\hline 1 & China Higher Education Research & 10 \\
2 & China Higher Education & 10 \\
3 & Modern Education Management & 10 \\
4 & Research in Higher Education of Engineering & 9 \\
5 & Heilongjiang Researches on Higher Education & 9 \\
6 & Jiangsu Higher Education & 9 \\
7 & China University Teaching & 9 \\
8 & Ideological Theoretical Education & 8 \\
9 & Research in Education Development & 8 \\
10 & Journal of National Academy of Education Administration & 8 \\
11 & Higher Education Exploration & 7 \\
12 & Journal of Higher Education Management & 7 \\
13 & Educational Research & 7 \\
14 & China Youth Study & 6 \\
15 & Chinese University Science and Technology & 6 \\
16 & Studies in Ideological Education & 6 \\
17 & Science and Technology Management Research & 6 \\
18 & Theory and Practice of Education & 5 \\
19 & Leading Journal of Ideological and Theoretical Education & 5 \\
\hline
\end{tabular}

\subsection{Scientific Co-authorships}

According to the definition given by Katz J. S and Martin B R, experts specializing in scientific metrology, for scientific collaboration, it means that researchers work together for the common purpose of producing new scientific knowledge. However, in a real process, scientific collaboration is manifested in various forms. The scientific collaboration mentioned here refers to the case in which different authors, institutions, countries and areas simultaneously appear in the same article. In this case, we think that there is a collaboration relationship between them ${ }^{[3]}$. Influenced by the objective factors, for example, the data of collected literature, this article is intended for discussing the scientific collaboration with respect to the academic circle in China in the research on innovation and entrepreneurship education at universities.

In Figure 2, a small or large dot in size represents a small or large number of the articles published by an author. Judging from Figure 2, the mode of research on the issue of innovation and entrepreneurship education at universities with respect to Chinese scholars is mainly characterized by individual research with collaborative research accounting for a small proportion. The collaborative research is mainly characterized by the research jointly done by two scholars with the research jointly done by three or more scholars accounting for a small proportion. In this figure, the big or small dot in size stands for the big or small number of published articles while the line represents the collaborative relationship between two authors. According to this figure, there are 10 scholars whose numbers of published articles reach 4 or more. Obviously, most of these scholars are the top scholars in the field of research on innovation and entrepreneurship education at universities. 


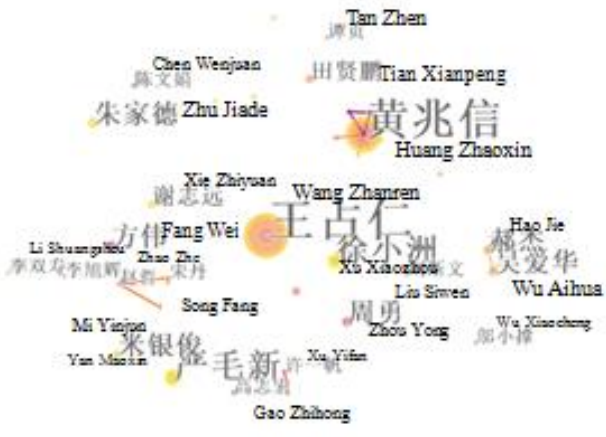

Figure 2 Analytical graph about the network of the collaboration between authors

Table 2. Prolific authors in the research on innovation and entrepreneurship education at Chinese universities

\begin{tabular}{lll}
\hline Count & Year & Authors \\
\hline 17 & 2015 & Wang Zhanren \\
14 & 2012 & Huang Zhaoxin \\
7 & 2017 & Yan Maoxin \\
6 & 2017 & Xu Xiaozhou \\
4 & 2013 & Fang Wei \\
4 & 2016 & Mi Yinjun \\
4 & 2016 & Hao Jie \\
4 & 2016 & Wu Aihua \\
4 & 2018 & Zhu Jiade \\
4 & 2013 & Zhou Yong \\
\hline
\end{tabular}

\subsection{Scientific Collaboration between Research Institutions}

Judging from Figure 3, as far as the field of research on innovation and entrepreneurship education at universities is concerned, the Chinese research institutions have a better collaboration than authors. In the research on the issue of innovation and entrepreneurship education, the mode of scientific collaboration with respect to institutions is mainly manifested by separate research assisted by collaborative research. Additionally, collaborative research is characterized by a strong concentration. In this figure, a small or large dot in size represents a small or large number of the articles published by an institution while the line stands for a collaborative relationship. Generally speaking, the collaboration and exchange between scientific research institutions are to be strengthened.

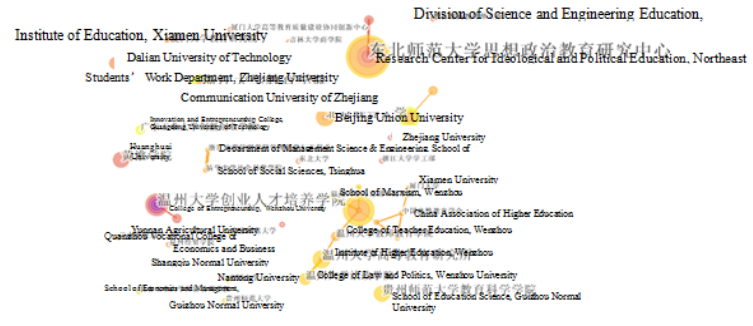

Figure 3 Analytical graph about the network of the collaborations between Chinese institutions
Of the numerous research institutions, the School of Innovation and Entrepreneurship under Wenzhou Medical University is an institution with the most concentrated scientific collaboration network, which has conducted scientific collaborations with four scientific research institutions including the School of Continuing Education under Renmin University of China and the School of Marxism under Wenzhou University. If the scientific research networks derived from the four aforementioned scientific research institutions are incorporated therein, the research network with the School of Innovation and Entrepreneurship under Wenzhou Medical University at its core is the most complicated scientific collaboration network in the field of research on innovation and entrepreneurship education at universities (see Figure 4).

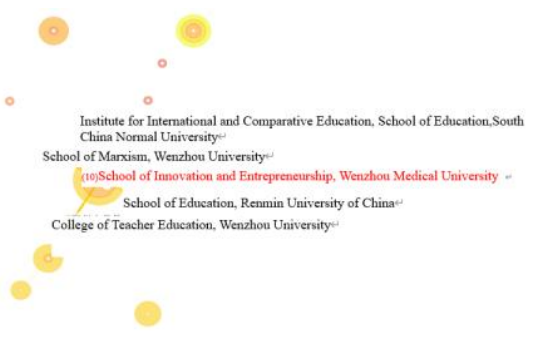

Figure 4 The scientific research collaboration network of the School of Innovation and Entrepreneurship, Wenzhou Medical University, China

In Figure 5, a small or big dot in size represents a small or big number of published articles. The Research Center for Ideological and Political Education of Northeast Normal University has the largest number of published articles. However, its scientific research collaboration network is somewhat simple. It has conducted the scientific research collaboration on the issue of innovation and entrepreneurship education at universities only with the Office of Student Affairs under Northeast Normal University.

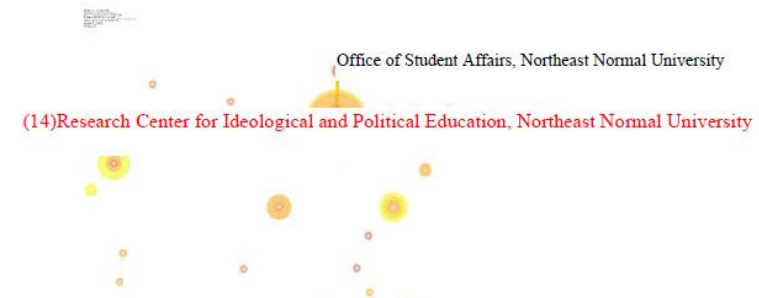

Figure 5 Scientific collaboration network of Research Center for Ideological and Political Education, Northeast Normal University, China

Table 3 shows the number of published articles of Chinese institutions on the issue of innovation and entrepreneurship education at universities. Of them, 11 institutions have the number of 4 or more published articles, which is in accordance with the number of 
authors with the number of published articles reaching 4 or more.

Table 3. Prolific Chinese research institutions engaged in the research on innovation and entrepreneurship education at universities

\begin{tabular}{llll}
\hline Count & Centrality & Year & Institutions \\
\hline 14 & 0 & 2015 & Research Center for Ideological and Political Education, Northeast Normal University \\
10 & 0.01 & 2016 & School of Innovation and Entrepreneurship, Wenzhou Medical University \\
8 & 0 & 2016 & College of Education, Zhejiang University \\
8 & 0 & 2011 & College of Entrepreneurship, Wenzhou University \\
7 & 0 & 2017 & Northeast Normal University \\
6 & 0 & 2016 & Beijing Union University \\
6 & 0 & 2017 & Institute of Higher Education, Wenzhou University \\
5 & 0 & 2015 & Huanghuai University \\
5 & 0 & 2018 & School of Education Science, Guizhou Normal University \\
4 & 0 & 2018 & College of Law and Politics, Wenzhou University \\
4 & 0 & 2016 & Graduate School of Education, Dalian University of Technology \\
\hline
\end{tabular}

4. ANALYSIS OF HOT RESEARCH TOPICS professional education, curriculum system and ecosystem AND TREND

\subsection{The Thread of Research on Innovation and Entrepreneurship Education at Chinese Universities}

Through the distribution of keywords in the time-zone chart, the article is dedicated to determining the thread of research on innovation and entrepreneurship education at universities. The years in the distribution in the shape of round are those that appeared for the first time. In the later research, the dots represented by the keywords will be enlarged if the words are applied to the research as keywords. In Figure 6, innovation and entrepreneurship education, entrepreneurship education and universities are three keywords that appeared for the first time in the field of research on innovation and entrepreneurship education at universities in 2008. In the subsequent research, terms such as entrepreneurial ability, are consecutively used in the research. In recent years, terms embodying the characteristics of the time such as mass entrepreneurship and innovation education, system of innovation and entrepreneurship education, construction of ecosystem, innovation-driven, maker space of universities and entrepreneurial culture have been gradually applied to research on innovation and entrepreneurship education at universities. This research is characterized by the extension from the initial research on topics such as innovation and entrepreneurship education and entrepreneurial education to the issues at the realistic level such as the attention paid to the improvement of entrepreneurial ability and the construction of curriculum system. And the keywords that have appeared in the past few years further indicate that the research on the field of innovation and entrepreneurship at universities with respect to the academic circle in our country has become deeper and been of more realistic significance.

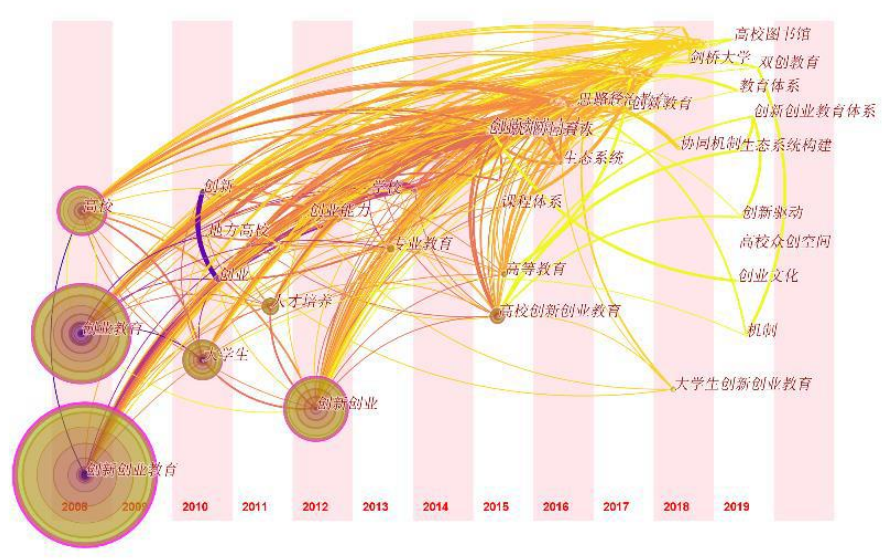

Figure 6 Time zone chart of new words concerning the research on innovation and entrepreneurship education at Chinese universities 


\subsection{Analysis of the Hot Topics about the Research on Innovation and Entrepreneurship Education at Chinese Universities}

Keywords are the core-the quintessence--of an article. They are the high generalization and condensation of an author's view. Therefore, it is necessary to make an analysis of the keywords of an article. Often, keywords will be employed to clinch readership status by relating to the hot topics in a given field of research. ${ }^{[5]}$ Based on the co-occurrence network (see Figure 7) of the keywords about the research on innovation and entrepreneurship education at universities, this article takes the table of the frequency of keywords (see Table 5) as an important basis and the distribution chart of the historical frequencies at key nodes as well as the table of the information of published literature as the main analysis object so as to clarify the hot research topic about innovation and entrepreneurship education at universities.

From Table 4, it is clear that the keyword with the highest frequency is "innovation and entrepreneurship education," which is consistent with our search. The keyword with the second highest frequency is "entrepreneurship education," which has an occurrence rate of 192 and centrality of 0.36 , indicating that there is a close relationship between "entrepreneurship education" and "innovation and entrepreneurship education at universities." The main intention for universities to carry out innovation and entrepreneurship education is to promote entrepreneurship education. Other keywords with the frequency number surpassing 10 include "innovation and entrepreneurship," "universities," "university students," "talent cultivation," "innovation and entrepreneurship education at universities," "professional education," "higher education," "local universities," "entrepreneurship education at universities," "entrepreneurship," "ecosystem," "innovative and entrepreneurial talents," "innovation of entrepreneurial ability," "ideological and political education," "university students' entrepreneurship," "collaborative innovation," "innovation and entrepreneurship education for university students," "entrepreneurial practice," "path" and "mode." (Please refer to Table 4.) The keywords listed above include many more words about education than words related to innovation and entrepreneurship education. In 2016, as a keyword, "ideological and political education" appeared in this research field, indicating that innovation and entrepreneurship education at the university level is not limited to the cultivation of students' innovative and entrepreneurial ability and the enhancement of their awareness regarding innovation. Additionally, it has incorporated education's educational function and value guidance into the system of cultivation through teaching. From the color depth of the annual ring of each and every word, it can be found that they will, in the near future, significantly influence innovation and entrepreneurship education at universities.

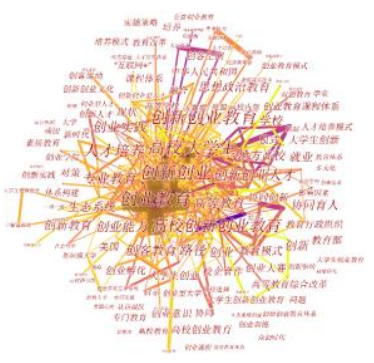

Figure 7 Co-occurrence network of the key words about the research on innovation and entrepreneurship education at Chinese universities

Table 4. Analytical graph about co-occurrence network of the key words about the research on innovation and entrepreneurship education at Chinese universities

\begin{tabular}{|l|l|l|l|}
\hline 实施策略 & Implementation strategy & 创新驱动 & Innovation-driven \\
\hline 培养模式 & Cultivation mode & 大学生创业教育 & $\begin{array}{l}\text { University students' entrepreneurship } \\
\text { education }\end{array}$ \\
\hline 教育改革 & Educational reform & 教育部 & Ministry of Education \\
\hline 研究综述 & Research overview & 教育行政组织 & educational administrative organization \\
\hline 人才培养体系 & Talent cultivation system & 协同育人 & Educate students in a synergistic manner \\
\hline "互联网+" & Internet plus & 影响因素培养体系 & Cultivation system of influence factors \\
\hline 课程体系 & Curriculum system & 众创空间 & Space of crowd innovation \\
\hline 创新创业型人才 & $\begin{array}{l}\text { Innovation and } \\
\text { entrepreneurship-oriented talents }\end{array}$ & 多元化 & Diversification \\
\hline 高等学校 & Institutions of higher learning & 就业 & Employment \\
\hline & 教育体系 & System of education \\
\hline 创客运动 & Maker movement & 大学生创新 & Innovation made by university students \\
\hline 创新创业文化 & $\begin{array}{l}\text { Innovation and entrepreneurship } \\
\text { culture }\end{array}$ & 人才培养模式 & Mode of talent cultivation \\
\hline 现状 & Current situation & 机制 & Mechanism \\
\hline 困境 & predicament & 创业教育课程体系 & $\begin{array}{l}\text { System of the courses of } \\
\text { entrepreneurship education }\end{array}$ \\
\hline 创业型人才 & Entrepreneurial talents & 双创教育 & Education of mass entrepreneurship and \\
\hline
\end{tabular}




\begin{tabular}{|c|c|c|c|}
\hline & & & innovation \\
\hline 创新人才 & Innovative talents & 学堂 & School \\
\hline 大学 & Universities & & \\
\hline 成因 & Cause & 虚拟技术 & Virtual technology \\
\hline \multirow[t]{2}{*}{ 新时代 } & New era & 创业教育模式 & Mode of entrepreneurship education \\
\hline & & 体验式教学 & Experiential teaching \\
\hline 素质教育 & All-round education & 论点 & Argument \\
\hline \multirow[t]{2}{*}{ 创业学院 } & Entrepreneurship academy & 经济新常态 & New normal of economy \\
\hline & & 人才红利 & talent dividend \\
\hline 创新实践 & Innovative practice & & \\
\hline 对策 & Countermeasures & 学术权力 & Academic power \\
\hline 大学生创新创业 & $\begin{array}{l}\text { University students-oriented } \\
\text { innovation and entrepreneurship }\end{array}$ & 互联网+ & Internet plus \\
\hline 体系构建 & System construction & & \\
\hline \multirow{2}{*}{ 一带一路 } & The Belt and Road Initiative & 供给国 & Supply countries \\
\hline & & 创客空间 & Space of makers \\
\hline 创新型人才 & Innovative talents & 中华人民共和国 & The People's Republic of China \\
\hline 社会创业 & Social entrepreneurship & 思想政治教育 & Ideological and political education \\
\hline 斯坦福大学 & Stanford University & 高校内容 & Contents concerning universities \\
\hline \multirow[t]{2}{*}{ 策略 } & Strategy & 欧盟 & The European Union \\
\hline & & 大数据 & Big data \\
\hline 高校图书馆 & University library & $\begin{array}{l}\text { 公益创业教育培养创 } \\
\text { 新创业教育 }\end{array}$ & $\begin{array}{l}\text { Social entrepreneurship education } \\
\text { cultivates innovation and } \\
\text { entrepreneurship education }\end{array}$ \\
\hline $\begin{array}{l}\text { 创业教育生态系 } \\
\text { 统 }\end{array}$ & $\begin{array}{l}\text { Ecosystem of entrepreneurship } \\
\text { education }\end{array}$ & 创业实践 & Entrepreneurial practice \\
\hline 剑桥大学 & University of Cambridge & 人才培养 & Talent cultivation \\
\hline 美国高校 & American universities & 高校大学生 & University students \\
\hline 协同发展 & Synergistic development & 专业教育 & Professional education \\
\hline 认识误区 & misunderstanding & 创新创业 & Innovation and entrepreneurship \\
\hline \multirow[t]{2}{*}{ 专门教育 } & Specialized education & 创业教育 & Entrepreneurship education \\
\hline & & 生态系统 & Ecosystem \\
\hline 高校教育 & University education & 创新教育 & Innovation education \\
\hline \multirow[t]{2}{*}{ 创业意识 } & Entrepreneurial consciousness & 创业能力 & Entrepreneurial ability \\
\hline & & 高校创新创业教育 & $\begin{array}{l}\text { Innovation and entrepreneurship } \\
\text { education at universities }\end{array}$ \\
\hline 启示 & Inspiration & 创客教育 & Education of makers \\
\hline 创业型大学 & Entrepreneurial universities & 创业孵化 & Business incubation \\
\hline \multirow[t]{2}{*}{ 路径选择 } & Path choice & 大学生创业 & University students' entrepreneurship \\
\hline & Practice & 路径 & Path \\
\hline $\begin{array}{l}\text { 大学生创新创业 } \\
\text { 教育问题 }\end{array}$ & $\begin{array}{l}\text { Issue on university students' } \\
\text { innovation and entrepreneurship } \\
\text { education }\end{array}$ & 校企合作 & University-enterprise cooperation \\
\hline 协同 & Synergy & 创业 & Entrepreneurship \\
\hline 高校创业教育 & $\begin{array}{l}\text { Entrepreneurship education at } \\
\text { universities }\end{array}$ & 校企合作 & University-enterprise cooperation \\
\hline 创业课程 & Entrepreneurship courses & 创业大赛 & Entrepreneurial contest \\
\hline 创业教育体系 & $\begin{array}{l}\text { System of entrepreneurship } \\
\text { education }\end{array}$ & 教育模式 & Educational pattern \\
\hline 生态系统构建 & Construction of ecosystem & 高等教育 & Higher education \\
\hline 创业训练 & Entrepreneurial training & 特征 & Characteristics \\
\hline 众创时代 & Era of crowd innovation & 协同创新 & Synergistic innovation \\
\hline $\begin{array}{l}\text { 创新创业教育体 } \\
\text { 系 }\end{array}$ & $\begin{array}{l}\text { System of innovation and } \\
\text { entrepreneurship education }\end{array}$ & 协同育人 & $\begin{array}{l}\text { Educating students in a synergistic } \\
\text { manner }\end{array}$ \\
\hline $\begin{array}{l}\text { 高等教育综合改 } \\
\text { 革 }\end{array}$ & $\begin{array}{l}\text { Comprehensive reform of higher } \\
\text { education }\end{array}$ & 创新创业人才 & $\begin{array}{l}\text { Innovation and } \\
\text { entrepreneurship-oriented talents }\end{array}$ \\
\hline
\end{tabular}


Table 5. Table of the frequencies of the key words about the research on innovation and entrepreneurship education at Chinese universities

\begin{tabular}{llll}
\hline Count & Centrality & Year & Keywords \\
\hline 260 & 0.44 & 2008 & Innovation and entrepreneurship education \\
192 & 0.36 & 2008 & Entrepreneurship education \\
121 & 0.39 & 2012 & Innovation and entrepreneurship \\
98 & 0.25 & 2008 & higher learning institutions \\
82 & 0.18 & 2010 & University students \\
38 & 0.14 & 2011 & Talent cultivation \\
38 & 0.2 & 2015 & Innovation and entrepreneurship education in universities \\
20 & 0.06 & 2013 & Professional education \\
19 & 0.04 & 2015 & Higher education \\
19 & 0.03 & 2010 & Local universities \\
18 & 0.01 & 2011 & Entrepreneurship education at universities \\
18 & 0.03 & 2010 & Entrepreneurship \\
15 & 0.07 & 2016 & Eco-system \\
14 & 0.07 & 2015 & Innovative and entrepreneurial talents \\
14 & 0.08 & 2012 & Entrepreneurial ability \\
13 & 0.03 & 2010 & innovation \\
13 & 0.02 & 2016 & Ideological and political education \\
12 & 0.04 & 2016 & university students' entrepreneurship \\
12 & 0.03 & 2013 & Synergistic innovation \\
12 & 0.01 & 2018 & Innovation and entrepreneurship education for university students \\
11 & 0.05 & 2015 & Entrepreneurial practice \\
11 & 0.04 & 2016 & path \\
10 & 0.01 & 2014 & mode \\
\hline
\end{tabular}

\subsection{Distribution of the Topics of the Research on Innovation and Entrepreneurship Education at Chinese Universities}

CiteSpace cluster analysis of keywords can intuitively reflect the topical distribution, topic issues and hot issues of the research in a field. This research makes a cluster analysis of keywords before deriving seven topical distributions in the field of innovation and entrepreneurship education at universities, including "innovation and entrepreneurship education at universities," "integration," "entrepreneurship," "talent cultivation," "countermeasures," "schools" and "businesses started by university students" (see Figure 8).

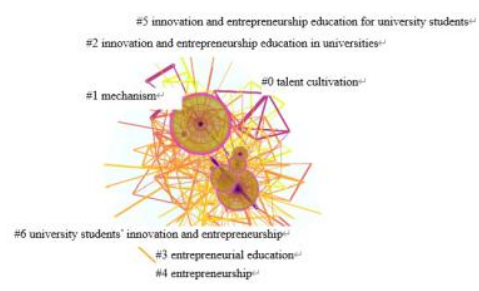

Figure 8 Chart of cluster analysis of new words

The integration in cluster 0 includes keywords such as "innovation and entrepreneurship education at universities," "innovative and entrepreneurial ability," "entrepreneurial practice," "maker education," "entrepreneurship contests" and "entrepreneurial incubation." This topical research is concentrated on the form and process of innovation and entrepreneurship education at universities.

The integration within cluster 1 includes keywords such as "innovation and entrepreneurship education," "professional education," "ideological and political education," "curriculum system" and "collaborative development." The topical research reflects the integration with various disciplines in the current development of innovation and entrepreneurship education in our country. The integration is characterized by not only the incorporation of professional courses but also the introduction of ideological and political education, thus enriching the research system of innovation and entrepreneurship education at universities.

The entrepreneurship in cluster 2 includes keywords such as "innovation and entrepreneurship," "path," "higher education innovation" and "entrepreneurship." This topical research focuses on the path and methods of entrepreneurship

The talent cultivation of cluster 3 includes keywords such as "institutions of higher learning," "university students," "employment," "innovation-oriented talents," "innovation academies" and "United States." The research under this topic mainly focuses on the content concerning the main body, objects and objectives of talent cultivation.

The countermeasures in cluster 4 include keywords such as "entrepreneurship education," "ecosystem," "innovation education" and "Chinese experience." The 
research of countermeasures mainly focuses on the exploration of innovation and entrepreneurship education experience with Chinese characteristics.

The schools in cluster 5 include keywords such as "local colleges and universities," "education of students in a synergistic manner," "synergistic innovation," "influencing factors," and "scientific and technological innovation." Under this topic, the research mainly focuses on content such as the supply side of innovation and entrepreneurship education as well as its influence and effect.

University students' entrepreneurship in clustering 6 includes four keywords such as misunderstandings, strategies, new normal and synergistic mechanism. Due to the small number of nodes, it is difficult to fully understand the specific content of research, which at the same time shows that the relevant literature is relatively meagre. However, as the important content of innovation and entrepreneurship education at universities, university students' entrepreneurship is somewhat reflective of the current situation characterized by the severe shortage of research on university students' entrepreneurship innovation and entrepreneurship at institutions of higher learning.

Table 6. Details of the cluster analysis of keywords

\begin{tabular}{llll}
\hline Cluster ID & Size & Silhouette & mean(Year) \\
\hline 0 & 27 & 0.616 & 2015 \\
1 & 25 & 0.624 & 2015 \\
2 & 23 & 0.774 & 2015 \\
3 & 23 & 0.782 & 2016 \\
4 & 14 & 0.686 & 2015 \\
5 & 12 & 0.859 & 2014 \\
6 & 10 & 0.879 & 2016 \\
\hline
\end{tabular}

\subsection{Analysis of the Trend of Research on Innovation and Entrepreneurship Education at Chinese Universities}

Emergent words refer to the words that appear repeatedly or are used frequently within a short period of time. The change in the frequency of emergent words can be used to judge the frontiers and trend of the research in that regard. In this research, 19 emergent words are classified into three stages before making interpretations of the frontier research issues in different stages as well as the research trend in the current stage (see Figure 9):

Stage 1: In this stage, which covers the period of 2008 to 2015, the keyword "entrepreneurship education" was used the longest. Moreover, keywords such as "entrepreneurship," "local universities," "entrepreneurship education at universities," "entrepreneurial ability," "Ministry of Education," "educational administrative organizations" and "school" were applied to research on innovation and entrepreneurship education at universities and thus became the frontier issues of research at this stage.

Stage 2: In this stage, which covers the period of 2015 to 2017, emergent keywords included "culture of innovation and entrepreneurship," "innovation," "maker education," "employment," "curricular system of entrepreneurial universities" and "countermeasures." The frontier issues at this stage mainly focused on the content, forms, main body and purposes of innovation and entrepreneurship education at universities.

Stage 3: This stage extends from 2017 to the present. Currently, the research frontiers in the field of innovation and entrepreneurship education at universities focus on innovation education,"Internet plus" and entrepreneurship academies. All the three emergent words give expression to a certain era characteristics and conform to the demand of the development of the times. 


\section{Top 19 Keywords with the Strongest Citation Bursts}

Keywords
Entrepreneurship education
Entrepreneurship
Local universities
Entrepreneurship education in universities
Entrepreneurial ability
Ministry of Education
Educational administrative organizations
School
Culture of innovation and entrepreneurship
Innovation
Maker education
Employment
Entrepreneurial universities
Curriculum system
Entrepreneurial consciousness
Counter-measure
Innovation education
"Internet plus"
Academies of entrepreneurship

Figure 9 The top 19 emergent words

\section{CONCLUSION}

By taking the sample with the topic of "innovation and entrepreneurship education at universities" collected by CNKI from 2008 to 2019, this article, with the help of a scientific visualization software called CiteSpace and working from the perspective of bibliometrics, has conducted the exploration of issues such as the evolution, the status of knowledge exchange and cooperation, research topics and research frontiers about the research on innovation and entrepreneurship education at universities before drawing the following conclusions:

a) The quantity of the literature in the field of research on innovation and entrepreneurship at universities is on the increase. The rate of increase has been significant since 2014, and it is expected to remain a hot issue of research.

b) The distribution of authors and institutions engaged in the field of research on innovation and entrepreneurship at universities is relatively dispersed, and the scientific collaboration is to be further enhanced.

c) The hot issues of research on innovation and entrepreneurship education at universities mainly focus on innovation and entrepreneurship education perse, university students, the cultivation of innovation-oriented talents and the role that a university should play in this process.

d) The keyword "ideological and political education" appears in both the distribution of hot topics and topics. In terms of hot research topics, it was in 2016 that "ideological and political education" was applied to research on innovation and entrepreneurship education at universities for the first time. As of this writing, it has been applied 13 times. In the distribution of topics, this

$\begin{array}{ccccc}\text { Year } & \text { Strength } & \text { Begin } & \text { End } & \text { 2008-2019 } \\ 2008 & 15.5329 & \mathbf{2 0 0 8} & 2014 & \\ 2008 & 4.5657 & \mathbf{2 0 1 0} & 2014 & \\ 2008 & 2.1069 & \mathbf{2 0 1 0} & 2011 & \\ 2008 & 2.3543 & \mathbf{2 0 1 1} & 2015 & \\ 2008 & 2.1115 & \mathbf{2 0 1 2} & 2014 & \\ 2008 & 2.5193 & \mathbf{2 0 1 3} & 2015 & \\ 2008 & 2.9318 & \mathbf{2 0 1 3} & 2015 & \\ 2008 & 2.5193 & \mathbf{2 0 1 3} & 2015 & \\ 2008 & 1.4665 & \mathbf{2 0 1 5} & 2016 & \\ 2008 & 1.2965 & \mathbf{2 0 1 5} & 2016 & \\ 2008 & 1.3356 & \mathbf{2 0 1 5} & 2017 & \\ 2008 & 2.5739 & \mathbf{2 0 1 5} & 2016 & \\ 2008 & 1.8349 & \mathbf{2 0 1 5} & 2016 & \\ 2008 & 1.5469 & \mathbf{2 0 1 5} & 2016 & \\ 2008 & 1.4404 & \mathbf{2 0 1 6} & 2017 & \\ 2008 & 1.4404 & \mathbf{2 0 1 6} & 2017 & \\ 2008 & 2.418 & \mathbf{2 0 1 7} & 2019 & \\ 2008 & 1.6074 & \mathbf{2 0 1 7} & 2019 & \\ 2008 & 1.3382 & \mathbf{2 0 1 7} & 2019 & \end{array}$

phrase is also included in the integration of cluster 1 . The introduction of "ideological and political education" to the research on innovation and entrepreneurship education at universities indicates a qualitative leap in the knowledge of problems with respect to this research field. Scholars certainly pay attention to innovation and entrepreneurship education perse and various subjects elicited by it, but they have also found the deep-seated educational function and value orientation of various kinds of education at universities behind this particular mode of education.

e) Innovation education, "Internet plus" and entrepreneurship academy constitute the frontier issues in the field of innovation and entrepreneurship education at Chinese universities. Of them, innovation education is elicited from traditional entrepreneurship education. In fact, entrepreneurship education is the training of basic skills and impartation of knowledge targeted at students with entrepreneurship as the orientation. However, innovation education constitutes the deepening and improvement of entrepreneurship education. In other words, this education is intended for not only teaching students basic skills but also consciously cultivating their innovative thinking and ability. Moreover, "Internet plus" is a hot issue in the current social environment. It is a challenging field with respect to innovation and entrepreneurship with respect to university students.

\section{PROJECT FUNDING}

It is the periodical achievement of cooperative education project of industry and education approved by Higher Education Department of Education Ministry titled College Students' Innovation and Entrepreneurship Incubation Platform Based on Cloud Computing. 


\section{REFERENCES}

[1] Ma Yongbin, Bai Zhe. Research and Practice Mode of China's Innovation and Entrepreneurship Education [J]. Tsinghua Journal of Education, 2015 (6): 99-103.

[2] Wang Zhanren.The Overall Plan of Reforming Education Ideas on HEI Innovation Entrepreneurship Education in China [J]. China Higher Education Research, 2015(7): 75-78.

[3] Li Jie, Chen Chaomei.CiteSpace: Text Mining and Visualization in Scientific Literature (2nd Edition)[M].Beijing: Capital University of Economics and Business Press, 2017.

[4] Qiu Junping, Yang Siluo, Song Yanhui. International Research Status, Hotspots and Frontier about Knowledge Communication Based on Mapping Knowledge Domain [J]. Journal of Library Science in China, 2012 (2): 78-89.

[5] Hou Haiyan, Liu Zeyuan, Chen Yue. Mapping of Science Studies the Trend of Research Fronts[J]. Science Research Management, 2006 (3): 90-96. 